\title{
Understanding of Travel Motivations of Domestic Tourists
}

\author{
Oyunchimeg Luvsandavaajav \\ Department of Geography, National University of Mongolia; Ulaanbaatar, Mongolia \\ Faculty of Business and Economics, University of Pecs, Pécs, Hungary \\ Gantuya Narantuya \\ Department of Geography, National University of Mongolia; Ulaanbaatar, Mongolia
}

Received: 20 March 2021. Revision received: 12 April 2021. Accepted: 14 May 2021

\begin{abstract}
Domestic tourism plays an essential role in the tourism industry and contributes to the overall economic development. This study aims to investigate the relationship between push and pull travel motivations of domestic tourists, their behavioral intentions, and a direct influence of travel motivations on perceived benefit, and perceived value of domestic tourists. The paper applies the concept of push and pull factors of travel motivation, perceived benefit, perceived value, and behavioral intention. The study implies a quantitative research method - questionnaire survey targeting domestic tourists in Mongolia between July to September 2019. A total of 1068 returned questionnaires were analyzed using factor analysis, reliability test, regression, path analysis, and SEM. The research result suggests that travel motivations (push and pull factors) were significant constructs of behavioral intentions. Moreover, the research results are significant for tourism practitioners, researchers, and destination managers to understand the motivational factors of domestic tourists, their perceived benefits and values, and behavioral intentions. The study outcomes could assist destination planners to develop new products and services or to enhance destination offer and tourist experiences by improving pull factors that include better service quality, various travel activities, ease of accessibility, reasonable pricing, and attractive environment; which latter lead to increase domestic tourist numbers and overall competitiveness of the destination.
\end{abstract}

Key Words: domestic tourists, push and pull travel motivations, perceived benefit, perceived value, and behavioral intentions

JEL Classification: C12, M31, Z31.

Reference: Oyunchimeg, L. \& Gantuya, N. (2021). Understanding of Travel Motivations of Domestic Tourists. Journal of Tourism and Services, 22(12), 1-22. doi: 10.29036/jots.v12i22.253

\section{Introduction}

Domestic tourism is one of the less researched studies by tourism academics and government bodies in developing countries (Canavan, 2013). However, many countries aim to develop domestic tourism as a tool for reducing poverty, developing infrastructure, and generating employment. Today, domestic tourism has become a central part of people's life. People travel within their countries to attend festivals, private and corporate events, religious ceremonies, and pilgrimages. The increase in disposable income, leisure time and development of infrastructure enabled a growing number of populations to engage in domestic tourism activities (Baniya \& Pandel, 2016). Aside from the economic benefit of domestic tourism, it has a great contribution to the social and cultural environment in a large scale. Jurigova and Lencsesva (2015) state that aside from value creation and income generation, the positive effects of tourism include environmental, social, and cultural effects. The increase in tourism movement 


\section{JOURNAL OF TOURISM AND SERVICES}

Issue 22, volume 12, ISSN 1804-5650 (Online)

www.jots.cz

has a positive impact on every country's economy and socio-cultural environment which leads to intensify competitiveness of the destination by improving tourism facility and infrastructure (Kozicka \& Szopa 2016).

Globalization and technology have brought substantial changes in reducing working hours and increasing holiday entitlement and disposable income, which cause the growth of domestic tourism in the world. An increase in disposable income and less working hours enable middle classes to participate in tourism activities in their respective countries. China, Indonesia, and Thailand are main contributors to the development of domestic tourism since these countries are densely populated and emerging economies. In general, domestic tourism has been represented as a recovery instrument for tourism crises and external shocks in the past (World Bank report, 2020). China and Thailand have encouraged domestic tourism during Covid-19 pandemic for maintaining employment and income of the tourism industry. While motivating the employees is considered one of the essential manager's skills (Hitka et al., 2021), employees also need to stay motivated from a long-term perspective (Závadský et al., 2015). China National Tourism Administration's statistic shows that China witnessed 10.7 percent growth in domestic tourism in 2018 by 5.5 billion domestic trips and US\$764 billion revenue (China National Tourism Administration, 2021). The economic contribution of domestic tourism in India is apparent, however it is less recognized by tourism practitioners. According to the Indian Ministry of Tourism report (2019) domestic tourism has grown from 220 million domestic visits in 2000 to 1.85 billion in 2018. India's government encourages developing domestic tourism as it directly contributes to the local job creation, redistribution of money from urban to rural areas.

Mongolia, a landlocked country located in Central Asia with a vast territory of $1.566 \mathrm{sq} \mathrm{km}$ but is inhabited only 3.2 million people. Mongolia has a great potential for tourism development due to its natural beauty, pristine environment and unique nomadic lifestyle. According to the report from the Ministry of Nature and Environment of Mongolia, the tourism industry has become an important contributor of the national economy which accounts for 7-8\% of the country's GDP and international tourist arrival was reached 577300 arrivals in 2019 (National Statistics Office, 2020). However, the government policies and tourism stakeholders have more focused on the international tourism volumes and expenditures in the last three decades, thus domestic tourism was largely ignored by government authorities and tourism stakeholders. Although Mongolians tend to travel more within their home country, domestic tourism remains a less recognized subject. However, domestic travel has been an integral part of nomadic herders who live in the vast territory of Mongolia in the past. Mongolians have very close family ties, which has a great impact on domestic travel patterns since visiting friends and relatives is a strong tradition among Mongolians. Similar to other countries, domestic tourism in Mongolia is determined by disposable income, labor activities, seasonality, tradition and holiday entitlements (Amartuvshin, 2009). Due to the foreign direct investment in the mining sector, government economic and structural policy, the standard of living has been substantially improved over the years. As household income increases, the majority of middle-class families acquire private vehicles which enable them to travel within the country. Improved road accessibility and paved road construction to the national parks and provinces caused a dramatic increase in domestic tourists. Urbanization and social congestion are another important reason to explain the rising demand of domestic tourism. Out of 3.2 million population, 1.4 million reside in the capital city Ulaanbaatar. As the climate is extremely continental, Mongolians experience a harsh, cold and long winter. Escaping from urban congestion, pollution and celebration of overcoming harsh winter are another major reason for Mongolians to travel in the summer period from June to September. In general, the increase in per capita income and quality of life, changing lifestyle, urbanization, vehicle ownership, ease of accessibility, and improvement of tourism infrastructures are main contributors to the recent boom in domestic tourism in Mongolia. Although domestic tourism's existence in Mongolia, the numbers and travel patterns and behavior of domestic tourists are uncertain. Domestic tourists' movement is problematic to track down since there is a lack of standardized measurement systems. The national parks' administration reports state that there 


\section{JOURNAL OF TOURISM AND SERVICES}

Issue 22, volume 12, ISSN 1804-5650 (Online)

www.jots.cz

were approximately 360000 domestic tourists entered in the 12 national parks of Mongolia in 2017 as shown in the entrance ticket statistics (Ministry of Environment \& Tourism, 2017). Despite the expansion of domestic tourism, little attention has been paid to the research on the travel motivations for Mongolian domestic tourists. It is crucial to understand the factors affecting domestic tourists' travel motivation, the relationship between factors, perceived benefit, and perceived value from domestic travel. In addition, positive behavioral intentions, perceived benefit and perceived value are related to some important outcomes, including delivering a positive impression about products and services; recommendation to others; intention to revisit and loyalty; more expenditure on products and services (Katsikari et al., 2020; Hwang et al., 2020). The examination of push and pull motivations, its relations to perceived benefits and value is critical for understanding domestic tourism demand, market segments, launching new products and services, and designing marketing strategy, and policy on destination development (Baloglu \& Uysal 1996). The study result contributes to the research gap on the determinants of domestic tourists' travel motivations, their perceived benefits and values, and intention to revisit and recommend to others.

\section{Literature review}

Motivation is a one of the most important reasons for human behavior to do action and to achieve goals or to move forward. Motivation derives from difference between psychological and biological desire, needs, want of human beings and their existing condition. Kotler and Armstrong (2017) state that motivation is a key determinant for consumer's decision-making process to purchase goods and services. Correspondingly, the tourist motivation is one of the key elements in tourist decision making behavior. A better understanding of tourist motivation plays a vital role in the prediction of travel behavior and patterns. The questions why do people travel, what motivates tourists to travel to a particular destination have been a debatable topic among tourism academicians (Katsikari et al., 2020; Hwang et al., 2020; Binder, 2004; Bayih \& Singh 2020; Correia et al., 2013; Agrawal, 2017; Wong et al., 2017; Keshavarzian \& Wu, 2017; Jang \& Cai 2002; Seyidov \& Adomaitiene 2016; Pereira et al., 2019). A widely accepted definition for tourist motivation is "biological and cultural forces that gives value and direction to travel choices, patterns, behavior and experiences" (Pearce, 2005). Mayo and Jarvis (1981) suggest that tourists and travelers are driven by the psychological factor and tourist behavior is explained by motivations. Travel decision making is complicated process with many sub-decisions that start even before deciding where to go and on-site decisions (Pan, 2015). Pre-trip decision process includes travelers deciding whether to travel or not, where to travel, what to do, when to travel, how long to travel and how much to spend (Oppewal et al., 2015). In order to answer these questions, travelers are required to assess competing destinations to select a place to visit for their next travel. The physical environment of the destination and personal value and motivations are analyzed by potential travelers in this assessment period (Mutinda \& Mayaka, 2012). In order to increase tourists' appeal and numbers, destinations need to appeal to tourist perceptions on both physical and cognitive components (Mussalam \& Tajeddini, 2016). Moreover, today's travelers are becoming independent from travel intermediaries, tour operators and travel agencies by using direct online booking services (Pan, 2015). Advances in information technology, search engines, user review-based websites have brought great challenges to the destination organizations as well as strong influence on the traveler's decision making on destination choice. Destination marketing and development strategy should be based on the factors that motivate travelers to visit to a specific destination. General and descriptive information of travel motivations is not significant enough in addressing effective product development and marketing. In this regard, it is essential to create an appropriate link between destination attributes and motivations of the targeted travelers' market by operative marketing campaign. It is important to understand travel motivations of tourists and tourist behavior on trip satisfaction. It has an implication on the intention to revisit and recommend to other travelers. Katsikari et al. (2020) state that the commonly recognized analysis of 


\section{JOURNAL OF TOURISM AND SERVICES}

Issue 22, volume 12, ISSN 1804-5650 (Online)

www.jots.cz

tourism motivation is based on push and pull factors of travel motivations. The analysis claims that people are pushed by their internal forces to travel, whereas they are fascinated by the special characteristics of a destination. Pull factors apply tangible and intangible attributes that define the attractiveness of the destination. On the contrary, most attributes of push factors are intangible and display the internal needs of travellers such as the need for relaxation, adventure, and prestige (Katsikari et al., 2020). Crompton's (1979) study identifies the conceptual framework of push and pull factors of travel motivation based on the destination selection behaviour of tourists.

Push factor- Push factor of travel motivation is mental activities of a person which are linked to the personal level of awakening (Iso-Aloha,1982). Push factors are identified by tourism researchers as escape from everyday routines, relaxation, exploration, social interaction, relationship enhancement, and prestige (Jensen, 2011). Gilbert and Terrata (2001) note that tourists seek unique experience, different cultures, refreshment, therefore novelty was important attribute for the tourist's decision making. Push factors refer to socio-psychological constructs that influence the tourist to participate in travel activities at the destination and affect their travel decisions (Bowen \& Clark, 2009; Lee et al., 2002). Push factors are considered as origin related, intangible and intrinsic desire of people (Uysal \& Hagan, 1993). It is determined by socio-psychological attributes which deals with the rationality of people go on holiday.

Pull factor- Why people travel is not only related to the psychological push factors. Swarbrooke and Horner (2005) emphasize a significance of the investigation of travel behavior, but it is not limited to the study of why people go on holiday (Plangmarn et al., 2012). Pull factor of travel motivation has become crucial for tourism practitioners to attract new and repeat visitors to the destination. Pull factor is characterized by the attributes, experiences, and products offered by destinations. It can be both intangible and tangible features of destinations that attract individuals. Attractiveness, activities and appreciation of the tourist destination are important to enhance tourists' perceived value, perceived benefit of the destination (Morrison, 2013). Destination attractiveness refers the geographic landscape appeal and number of attractions at the destination. Hospitality and feeling of welcoming are included in the appreciation yet intangible attributes of the destination. Kassean and Gassita (2013) identify that top five attributes of Mauritius that affect traveler's decision to visit were beaches, climate, weather, landscape and exotic scenery. Oppewal et al. (2015) classify tourist destination experience into two categories including service infrastructure that consists of transportation, travel service, accommodation service, food beverage service, shopping service, recreation and attraction service. The latter is a category with natural environment, political and legal, economic, social, cultural, and technological factors. These categories are the pull factors of the destination which influence on the tourists' perceived experience at the destination as well as decision making for choosing destination as their holiday place.

Perceived benefit - The notion of perceived benefits has been widely researched in the tourism (Frochot \& Morrison, 2001; Dolnicar et al., 2014; Sirgy et al., 2010). Nonetheless, there is a lack of study on the individual's perceptions of travel benefit. Perceived benefit of tourism is defined as the desirable consequences that seek from taking travel, holidays and vacations away from people's usual environment (Chen \& Petrick, 2014). Despite the fact that the tourists' perceived benefits and value have attracted attentions in tourism research, there are other fields of study such as organizational behavior (Westman et al., 2008), and health sciences (Bloom et al., 2010). These studies are interested in the relationship of perceived benefits of travel and people's workplace behavior and mental and physical health status. Lin et al. (2009) reveal that motives behind the desire to purchase tourism products and services include functional (extrinsic needs) and non- functional (intrinsic need). Functional need refers to emotional and psychological attributes such as enjoyment, which are fundamentally significant to tourism industry. Therefore, the positive emotional state has a critical influence on tourists' perceived benefits. A provision of benefit needed to tourists visiting at the destination is a key to create a successful tourism development and marketing. Terblanche and Taljaard (2018) 's study identified six perceived benefits as those perceived by tourists when they use travel agents to make travel arrangements such as convenience, customization, expertise, support and financial and emotional benefits. Wang and Fesenmaier's (2004) study on the 


\section{JOURNAL OF TOURISM AND SERVICES}

Issue 22, volume 12, ISSN 1804-5650 (Online)

www.jots.cz

benefits of online travel community members identified four categories of benefits including functional benefit (knowledge acquiring, learning); psychological benefit (sense of belonging, satisfaction); social benefit (better communication and interaction with others) and hedonistic benefits (more leisure time, relax and enjoyment). Moreover, Yen et al. (2011) propose three types of perceived benefits of participation in online travel communities as self-enhancement, rewards, and problem solving. In this study, four benefits (learning or knowledge acquiring, self-esteem, social, and hedonic) are proposed to be analyzed relationship between push and pull travel motivations, and behavioral intention. Learning benefits refer to personal growth, increase in life skill, and obtaining knowledge through travelling. Boydell (1976) defines experiential learning as a meaningful discovery that occurs when learners discover knowledge on their own through personal experiences. Social benefits refer to the enhancement of social relationship through interaction with the community that provides a sense of belonging and social identity (Nambisan \& Baron, 2009). Self-esteem benefit is identified as better individual status and reputation. Hedonic benefits are the pleasure obtained through the travel experience with the tourism service and associated with individual feelings (Chen \& Petrick, 2013). Tourists purchase tourism goods and services for the perceived benefit they will gain from it. These perceived benefits with additional opinions about goods and service create tourists' perceived value about the overall destination. Therefore, it is a fact that, the perceived benefits are the precedent variables of perceived value and behavioral intention of tourists.

Perceived value- Value is the result of a mental assessment which refers to rules, criteria, and standards (Holbrook, 1999). Perceived value of goods and services positively affects customer's satisfaction and behavioral intention (Chen \& Petrick, 2014). Xiaoting et al. (2020) define that perceived value is an outcome of overall product and service evaluation against sacrifice to obtain the desired product or service. Perceived value depends on the type of goods and services, therefore, measurement varies by areas (Lee et al., 2007). Thus, tourism stakeholders at the destinations put more efforts on enhancing perceived value of current and potential tourists, since perceived value impacts on overall satisfaction, intention to return and recommend to others (Yu \& Goulden, 2006). Niemczyk and Seweryn (2014) state that satisfaction produces emotional loyalty to the tourist destination that spreads positive opinions about destination experiences among family, friends, colleagues, and internet users. A number of research works have dedicated to the importance of tourists' perceived value regarding to service quality and satisfaction at tourist destinations (Xiaoting et al., 2020; Lee et al., 2007; Oh, 1999; Petrick, 2002; Ryu et al., 2008; Sanchez et al., 2006). The tourists' perceived value of the destination influences on their revisit intentions and recommendations to others. Chen and Petrick (2014) state that perceived value is a reaction of the feelings and attitudes of a tourist in regard to a product or service purchased. Perceived value reflects on the price of the goods and service, and the psychological attributes of perceived quality and emotional response (Chen \& Fu, 2010). Parasureman and Grewal (2000) state that it is crucial to determine tourists' perceived value which affects their behavioral intentions. In tourism research, the perceived value is the tourists' overall evaluation of the utility of tourism products and services based on the perception which is given. In addition, Wearing and Deane (2003) 's study reveals that the interaction between tourists and places, people and activities supports individuals to understand self and others that reflects on the perceived value of the travel. Brown and Lehto (2005) note that satisfaction from overall travel experience and self-fulfillment directly related to the interaction with local community, travel memories, and enhancement of family relationships. Tourist perceived value at the destination (Chen \& Tsai, 2008), and perceived quality of the services offered may influence on their satisfaction and behavioral intentions (Bigné et al., 2001). Xiaoting et al. (2020) state that perceived value is a crucial antecedent in tourist behavioural studies, moreover in its ability to make prediction of overall tourist satisfaction and destination loyalty. There has been limited empirical research conducted on perceived value and its relationship to travel motivation, precisely the push and pull factors of travel motivations, perceived benefits, and behavioral intention. Therefore, evaluation of the perceived value of tourists and its influence on tourists' decision-making has seldom been conducted in domestic tourists' context. The proposed research model in this study aims to examine relationship between tourist 


\section{JOURNAL OF TOURISM AND SERVICES}

Issue 22, volume 12, ISSN 1804-5650 (Online)

www.jots.cz

motivations, perceived benefits, perceived value, and behavioral intentions of domestic tourists in Mongolia.

Tourist behavioral intentions- Behavioral intention is a tourist assessment about the possibility of revisiting to the same destination or the tourists' willingness to recommend the destination to the potential tourists (Chen \& Tsai, 2007). Zeithaml et al. (1996) identify the determinants of tourist behavioral intentions as repurchase intentions, word of mouth recommendation, customer loyalty complaints, and price sensitivity. Excellent quality of tourism service often brings favorable behavioral intentions whereas worse service quality leads to unfavorable intentions. Chen and Chen (2010) note that favorable travel intention represents customer loyalty including positive word of mouth (recommendation), spending more money at the destination, paying premium price, and being loyal to the destination. Burton et al. (2003) summarize that previous tourist behavioral research determined behavioral intentions using three attributes; intention to return, willingness to recommend and word of mouth. Moreover, a positive customer experience brings more likeliness to reuse the service. Favorable tourist intentions represent the customer loyalty of the tourists to a destination. Customer loyalty is an important objective of tourism marketing as it is a key attribute for destination competitiveness. Customer loyalty and retention of existing customers requires lower marketing costs than bringing new customers. Moreover, loyal tourists are more likely to recommend to friends, relatives, or potential customers to travel to the same destinations by delivering free word-of-of-mouth advertisements (Shoemaker \& Lewis, 1999). Lee and Lee (2009) note that customer loyalty is a crucial factor for the success of destination marketing strategy. Tourism practitioners evaluate their marketing and management strategies based on the behavioral intentions of tourists, the willingness of tourists to recommend others, and deliver a positive word of mouth about their destination experiences.

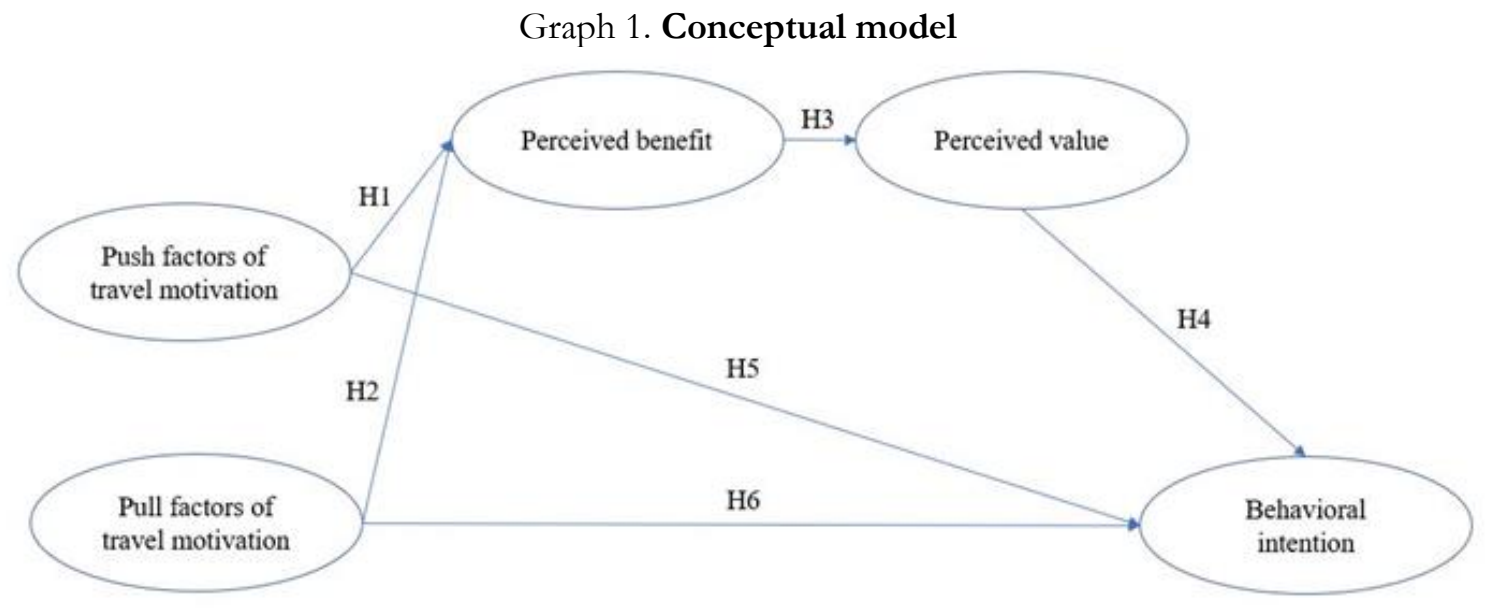

Source: Own literature research

There are numbers of research dedicated to the relationship between travel motivations and overall tourist satisfactions and tourists' behavioral intentions. Tourist motivations have determined as antecedents of tourist satisfaction and destination loyalty (Lee, 2009; Yoon \& Uysal, 2005). Therefore, tourist behavioral intentions have been anticipated by tourist motivations. Moreover, push and pull motivations have a positive relationship with tourist satisfaction and behavioral intentions (Khoung \& $\mathrm{Ha}, 2014)$. As perceived benefits and perceived value are key determinants for identifying overall tourist satisfactions, and behavioral intentions, there is a limited research among tourism literature regarding to the direct and indirect relationship between push and pull travel motivations, perceived benefits, perceived value and behavioral intention. Therefore, based on the literature review, this research purposes following hypotheses: 


\section{JOURNAL OF TOURISM AND SERVICES}

Issue 22, volume 12, ISSN 1804-5650 (Online)

www.jots.cz

H1: Push factors of travel motivation directly and positively influence on perceived benefit.

H2: Pull factors of travel motivation directly and positively influence on perceived benefit.

H3: Perceived benefit directly and positively affects perceived value.

H4: Perceived value directly and positively affects tourist behavioral intentions.

H5: There is a significant relationship between push factors of travel motivations and domestic tourist behavioral intention.

H6: There is a significant relationship between pull factors of travel motivations and domestic tourist behavioral intention.

\section{Methodology}

This study employs a quantitative approach to investigate push and pull factors of motivations with an accordance of domestic tourists in Mongolia; to examine the relationship between tourist motivations, perceived benefits, perceived value, and behavioral intention. Based on the literature review of the travel motivations, push and pull factor, perceived benefits, perceived value, and travel intentions, following research model was developed (Graph 1).

Data sampling-The target population was Mongolians who reside in the capital city of Ulaanbaatar and participated in the domestic tourism activity recently. More than half of Mongolian $3.2 \mathrm{mln}$ population reside in the capital city Ulaanbaatar. Therefore, the majority of domestic tourists travel from Ulaanbaatar to the rest of the country. Due to the limited data on domestic tourists, it was problematic to draw the sampling frame. However, the researchers used a random sampling technique to collect data from the target population. The questionnaire survey was conducted at the five sites in Ulaanbaatar between the months of July and September 2019. The survey was administered at the State Department Store, supermarkets, Sukhbaatar square, main street in the student campus, and Gandan Monastery. Every tenth person was approached by researchers and asked to participate in the survey. The pilot testing was conducted prior to actual sampling and corrections were made. The data were collected via selfadministered and printed questionnaire in Mongolian language. The questionnaire was consisted of 80 close-ended questions including 21 questions for push factors of travel motivations; 20 questions for pull factors of travel motivations; 13 questions for perceived benefit and 18 questions for perceived value, 3 questions for behavioral intentions and 5 questions for demographic profile of the respondents. The survey was designed to provide a comprehensive understanding of domestic tourists' travel motivations, their perceived benefits and perceived values and behavioral intentions. The researchers aim to achieve the proposed sample of 1300 with $10 \%$ to $15 \%$ nonreturn rate. The usable and complete sample size was 1068 , with response rate of $82.1 \%$.

Research instrument - In this study, the hypotheses were analyzed using structural equation modeling (SEM). Malhotra (2007) proposes data analysis techniques and its required sample size depends on factors. The data analysis technique proposed in this study is confirmatory factor analysis (CFA), which is precise to sample size and less stable when assessed in small samples (Tabachnick \& Fidell, 2007). Hair et al. (2010) suggest that there is no widely accepted criteria for definition of exact sample size using CFA except SEM. Thus, Hair et al. (2010) purpose that the minimum sample size is 100 when consider a model containing five or fewer constructs; and three or more items each have high item commonality. In general, the actual minimum size for using SEM is considered 100 (Hair et al., 2010). Moreover, Cliff (1987) recommends a sample size of 150 for 40 variables (item description) on the scale. A variety of heuristics can be used to calculate the pre-statistical power analysis. According to the time standard of SEM using AMOS, the sample size used should be at least 5 times the number of indicators (Pallant, 2005). SEM is a covariance-based approach that use model fitting to compare the proposed research model to the best possible model fit. In addition, SEM is focused on explaining and it is a more suitable tool for theory testing (Hair et al., 2010). 


\section{JOURNAL OF TOURISM AND SERVICES}

Issue 22, volume 12, ISSN 1804-5650 (Online)

www.jots.cz

Push and pull tourist motivations were measured by items designed by previous research studies (Jang \& Cai, 2002; Yoon \& Uysal, 2005; Park et al., 2015; Kozak, 2002). The respondents were asked to indicate 41 motivational attributes in selecting domestic travel destinations within Mongolia. The importance of attributes measured on five-point Likert scale (5 being strongly agree and 1 strongly disagree). As a literature review of push and pull factors of travel motivations suggested 21 of these 41 attributes were in the push category and the remaining 20 in the pull category. Questions for measuring perceived benefit and perceived value were similarly based on the literature review findings (Nambisan \& Baron, 2009; Kuo \& Feng, 2013) with 13 attributes of perceived benefit and 18 attributes of perceived value by using five-point Likert scales ( 5 being strongly agree and 1 strongly disagree). The measurement of behavioral intention was developed on the 3 items adopted (Muhammed et al., 2016; Kwenye \& Freimund, 2016) which the latter categorized into revisit intentions, and recommendation to others. Data was analyzed by using SPSS 23.0 statistical software program and produced descriptive and inferential statistics. In addition, SPSS, AMOS and excel programs were used for data presentation, tabulation, and graphs.

The research respondents' demographic profile is shown in the Table 1, out of the total 1068 respondents, $613(57.3 \%)$ were female, $449(42.2 \%)$ were men and $6(0.5 \%)$ respondents were identified their gender as other. There are slightly different distributions between age groups with $634(59 \%)$ for 18-30 years old, 255 (23.9\%) for 31-40 years old, 135 (12.6\%) for $41-50$ years old; and $34(3.2 \%)$ for 5160 years old. The majority of the respondents 585 (54.5\%) travelled with the family; $212(19.9 \%)$ with friends; $105(9.8 \%)$ with relatives and only $83(7.8 \%)$ were travelled with tour groups. In terms of monthly income, $255(23.9 \%)$ respondents earn between US\$281-350; 238 (22.3\%) respondents earn less than US $\$ 175 ; 202(18.9 \%)$ respondents earn between US\$351-530; 167(15.6\%) respondents earn between US\$176-280; $116(10.9 \%)$ respondents earn between US\$531-700; only 90 (8.4\%) respondents earn US\$701 and above.

Table 1. Demographic characteristics of the respondents $(\mathrm{N}=1068)$

\begin{tabular}{|c|c|c|c|}
\hline Characteristics & Categories & Number & $\%$ of sample \\
\hline \multirow{3}{*}{ Gender } & Male & 449 & 42.2 \\
\hline & Female & 613 & 57.3 \\
\hline & Others & 6 & 0.5 \\
\hline \multirow{6}{*}{ Age } & $18-20$ years old & 265 & 24.8 \\
\hline & $21-30$ years old & 369 & 34.6 \\
\hline & $31-40$ years old & 255 & 23.9 \\
\hline & $41-50$ years old & 135 & 12.6 \\
\hline & $51-60$ years old & 34 & 3.2 \\
\hline & Over the $60 \mathrm{~s}$ & 10 & 0.9 \\
\hline \multirow{6}{*}{ Traveling with } & Alone & 73 & 6.8 \\
\hline & Tour group & 83 & 7.8 \\
\hline & Family & 585 & 54.8 \\
\hline & Friends & 212 & 19.9 \\
\hline & Relatives & 105 & 9.8 \\
\hline & Colleagues & 10 & 0.9 \\
\hline \multirow{6}{*}{ Monthly family income (\$) } & $85-175$ & 238 & 22.3 \\
\hline & $176-280$ & 167 & 15.6 \\
\hline & $281-350$ & 255 & 23.9 \\
\hline & $351-530$ & 202 & 18.9 \\
\hline & $531-700$ & 116 & 10.9 \\
\hline & $701-880$ & 60 & 5.6 \\
\hline
\end{tabular}




\section{JOURNAL OF TOURISM AND SERVICES}

Issue 22, volume 12, ISSN 1804-5650 (Online)

www.jots.cz

\begin{tabular}{|l|l|l|l|}
\hline & Above 881 & 30 & 2.8 \\
\hline
\end{tabular}

Source: Own research

\section{Results}

Exploratory Factor Analysis- To assess the dimensionality of the 41 items, Exploratory Factor Analysis (EFA) was conducted. Out of 1300 questionnaires, 1089 were filled in and returned. The final sample size was 1068 after data cleaning. To reduce the number of items, the factor loading values that indicate the correlation between items and factors were identified whether the group of variables can be presented by the factor or not. The eigenvalue one was determined and items with factor loadings greater than 0.5 were taken for each factor grouping. Cronbach's $\alpha$ was applied to test reliability of factor groupings. The factors with Cronbach $\alpha$ greater than 0.6 were taken to the analysis. The mean scores of the push and pull factors of travel motivations were analyzed to identify what factors were perceived more important among respondents. The EFA result indicates that four push motivations and four pull motivations' factors are significantly correlated, which are shown in Tables 2 and Table 3. Five items were excluded from push motivations, while two items were excluded from pull motivations as they could not survive the model diagnostic procedure. The purification of items for searching for model specifications (Hair et al., 2010) was performed. The result of the CFA of the modified models of the push and pull travel motivations are summarized in Table 4.

Table 2. EFA and reliability test results of Push factor of travel motivation

\begin{tabular}{|c|c|c|}
\hline PUSH FACTORS & Loading & Cronbach $\alpha$ \\
\hline \multicolumn{2}{|l|}{ Factor 1: Self exploratory } & \multirow{5}{*}{0.782} \\
\hline Travel can enhance knowledge and experience & 0.735 & \\
\hline $\begin{array}{l}\text { Travel enables me to fulfil my dreams and self-curiosity about places } \\
\text { that I want to visit }\end{array}$ & 0.693 & \\
\hline I can learn new things or different lifestyle when I travel & 0.771 & \\
\hline I can learn new and interesting things while travelling & 0.696 & \\
\hline \multicolumn{2}{|l|}{ Factor 2: Relax and escape } & \multirow{6}{*}{0.798} \\
\hline I can rest and relax & 0.623 & \\
\hline I would feel happy and excited in tourist places & 0.561 & \\
\hline Makes me feel pleased and relaxed in Mongolia & 0.751 & \\
\hline Gain joy and happiness in Mongolia & 0.734 & \\
\hline Make me feel inspired in Mongolia & 0705 & \\
\hline \multicolumn{2}{|l|}{ Factor 3: Social } & \multirow{4}{*}{0.734} \\
\hline I expect to meet people with similar interests when I travel & 0.670 & \\
\hline $\begin{array}{l}\text { I could share my life, work, travel experiences with people who I know } \\
\text { or who are new to me when I travel }\end{array}$ & 0.643 & \\
\hline I could increase my social status if I travel & 0717 & \\
\hline \multicolumn{2}{|l|}{ Factor 4: Togetherness } & \multirow{5}{*}{0.769} \\
\hline I could communicate with the local community or other tourists & 0.719 & \\
\hline Meeting and chatting with local people could be interesting & 0.764 & \\
\hline Meeting and chatting with other tourists could be entertaining & 0.765 & \\
\hline I enjoy visiting friends and relatives who lived in other places & 0.620 & \\
\hline
\end{tabular}

Source: Own research

Table 3. EFA and reliability test results of pull factors of travel motivations

\begin{tabular}{|c|c|c|}
\hline PULL FACTORS & Loading & Cronbach $\alpha$ \\
\hline Factor 1: Natural & & \multirow{2}{*}{0.805} \\
\hline It has many attractions & 0.746 & \\
\hline
\end{tabular}




\section{JOURNAL OF TOURISM AND SERVICES}

Issue 22, volume 12, ISSN 1804-5650 (Online) www.jots.cz

\begin{tabular}{|l|l|}
\hline It has beautiful scenery & 0.752 \\
\hline It has calm atmosphere & 0.805 \\
\hline It has a pleasant climate & 0.677 \\
\hline It has nice lakes and rivers & 0.650 \\
\hline Factor 2: Events and festivals & 0.729 \\
\hline Active nightlife & 0.755 \\
\hline Sightseeing & 0.684 \\
\hline Entertainment & 0.771 \\
\hline Sport activities & 0.740 \\
\hline Cultural activities & \\
\hline Factor 3: Easy access to service & 0.854 \\
\hline Offers good facility to elderly & 0.852 \\
\hline Offers good facility to children & 0.818 \\
\hline Hospitality & \\
\hline Factor 4: Cultural & 0.690 \\
\hline Local cuisine, airag (fermented mare's milk) & 0.624 \\
\hline Friendly locals & 0.593 \\
\hline Heritage & 0.556 \\
\hline History & \\
\hline KMO = .899; Bartlett's Test of Sphericity, p value $=.000$. & \\
\hline
\end{tabular}

Source: Own research

Table 4. Fit Measures for the CFA Models

\begin{tabular}{|l|c|c|c|}
\hline \multicolumn{1}{|c|}{ Fit indexes } & PUSHM & PULLM & Acceptable level \\
\hline Chi-square & 375.105 & 443.436 & \\
\hline Degree of freedom (df) & 98 & 35 & .000 \\
\hline P & .000 & 96.196 & $>.05$ \\
\hline Normed chi-square (CMIN/DF) & 42.854 & .923 & $\geq .90$ \\
\hline Goodness-of-fit index (GFI) & .931 & .876 & $\geq .90$ \\
\hline Adjusted goodness-of-fit index (AGFI) & .905 & .879 & $\geq .90$ \\
\hline Tucker-Lewis index (TLI) & .932 & .909 & $\geq .90$ \\
\hline Comparative fit index (CFI) & .951 & .104 & $\leq .08$ \\
\hline $\begin{array}{l}\text { Root mean square of error of estimation } \\
\text { (RMESA) }\end{array}$ & .051 & \\
\hline Note. PUSHM = push motivations; PULLM = pull motivations \\
\hline
\end{tabular}

Source: Own research

Push motivations- The CFA result indicates that the push motivation structure fit well into the data after two iterations, when three dimensions of push factors of travel motivations (items of push 5, push 6, push 9) were deleted due to negative covariance with two other dimensions. Moreover, the items of push 10, push 17 were deleted due to the low squared multiple correlations (SMC) value. Therefore, absolute fit indices through the normed Chi-square value (CMIN/DF), root mean square error of approximation (RMSEA) and P of close fit (PCLOSE) were analyzed. The analyzed indices results showed the acceptable levels (CMIN/DF; 3.828; RMSEA; 0.051; PCLOSE; 0.374) (Hair et al. 2010). Both Tucker-Lewis index (TLI) (0.932) and comparative fit index (CFI) (0.951) indices were well above the threshold of 0.9 , which indicate a good incremental fit. The parsimony fit index of PNFI (0.674) was above the 0.5 value suggested by Mulaik et al. (1989). Finally, the Hoelter's (1983) critical N for 0.5 (355) and 0.1 (388) were well above the desirable value of 200 as proposed by Hoelter's (1983) study. All items were significant at the 0.05 level of standardized regression weight from 0.67 onwards $(>0.5$ as suggested by Hair et al (2010). The squared multiple correlations were between 0.45 and $0.75(>0.4)$ by reflecting all items were significantly associated with their respective latent variables as indicated in the research hypotheses. The average variance extracted (AVE) ranged from 0.517 to 0.600 (threshold; 0.5 ) while the 


\section{JOURNAL OF TOURISM AND SERVICES}

Issue 22, volume 12, ISSN 1804-5650 (Online)

www.jots.cz

CR value spans were between 0.731 and 0.810 (threshold; 0.7). The results show that the research model has a good convergent validity and high level of consistency of relevant items in the measurement of the same construct. The square root of the AVE ranged from 0.719 to 0.774 . The CFA result verified that all the variables have high levels of discriminant validity. The measurement model for PUSH-M after the second iteration is shown in Graph 2.

Graph 2. Measurement model for push factors of travel motivation

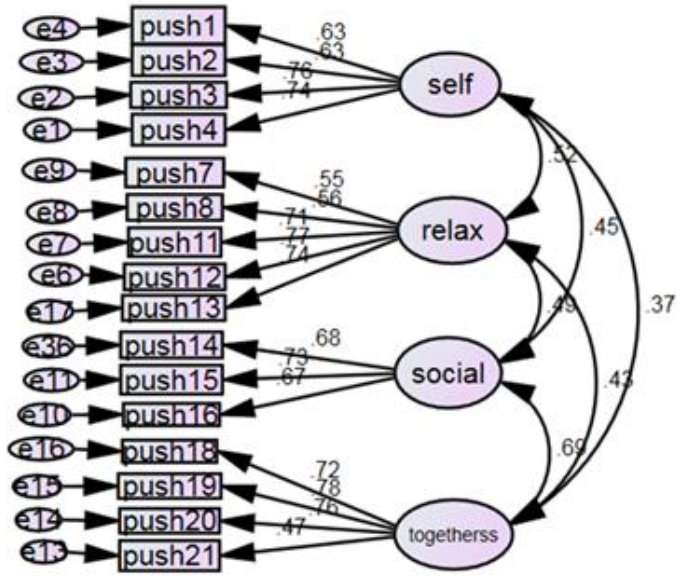

Source: Own research

Pull motivations- The CFA results indicate that the pull travel motivation structure well fit into the data after four iterations when the items of and pull 7, pull 6, pull 13 were deleted due to undesirable high standardized residual covariance (SRC) while items of cultural and easy access to service factors as pull 9 , pull 10, pull 11, pull 12, pull 18, pull 19, and pull 20 were deleted due to the unidentified values. Absolute fit indices were performed above the acceptable levels (CMIN/DF; 96.196; RMSEA; 0.296; PCLOSE; 0.000). The TLI $(0.879<0.9)$ and CFI $(0.909)$ were well above the threshold of 0.9, which indicate good incremental fit. Moreover, the parsimony fit index of PNFI (0.687) was above the value of 0.5. Although Hoelter's (1983) critical N 0.5 (125) and 0.1 (144) were below the desirable value of 200 which was proposed by Hoelter (1983), the sample size could be considered as adequate since the numbers were above the threshold of 75 (Kenny et al., 2014). All items were significant with standardized regression weight above the value of 0.5 . As it is an exploratory study, these items were retained since standardized regression weight was at acceptable level. The measurement model for Pull travel motivation after four iterations is shown in Graph 3.

Graph 3. Measurement model for pull factor of travel motivation 


\section{JOURNAL OF TOURISM AND SERVICES}

Issue 22, volume 12, ISSN 1804-5650 (Online)

www.jots.cz

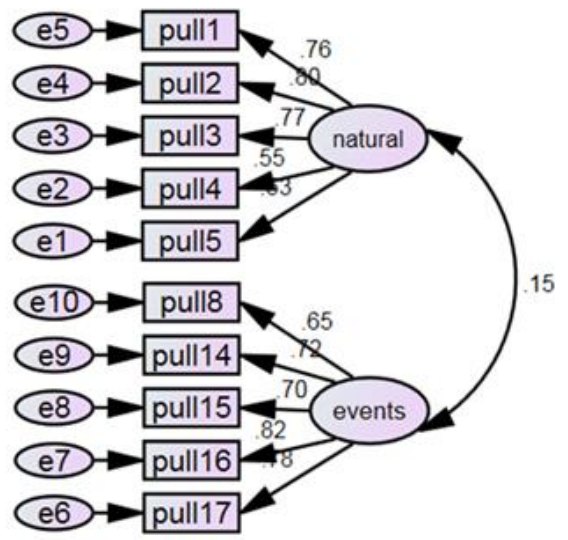

Source: Own research

Basic structural model- The basic structural model as proposed in the theoretical framework of the study is shown in Graph 4. This model tested two hypotheses as push factor of travel motivations (PUSHM) and Pull factor of travel motivations (PULLM) were the independent variables and behavioral intention was the dependent variable. The results show that both PUSHM and PULLM have a positive relationship with behavioral intention and the relationship was significant $(\mathrm{p}<0.05)$. All indicators show a good absolute model fit by one iteration (CMIN/DF; 5.907, RMSEA; 0.067; CFI; 0.839, TLI; 0.808, PNFI; 0.683). All of the two direct relationships were significant at the level of 0.05 . In addition, the basic structural model result provides answers to which push and pull factors of travel motivations are most important and affect to the tourists' behavioral intentions. In total, 15 items (5 items from the Push motivations and 10 items from pull motivations) were deleted from the first order measurement assessment. The first-order measurement model was assessed by the combination of all constructs (push motivations, pull motivations, and revisit intentions). The CFA result indicates that whether model structure fits into the data well in a single iteration. The basic structural model is shown in Graph 4.

\section{Graph 4. Basic Structural Model}

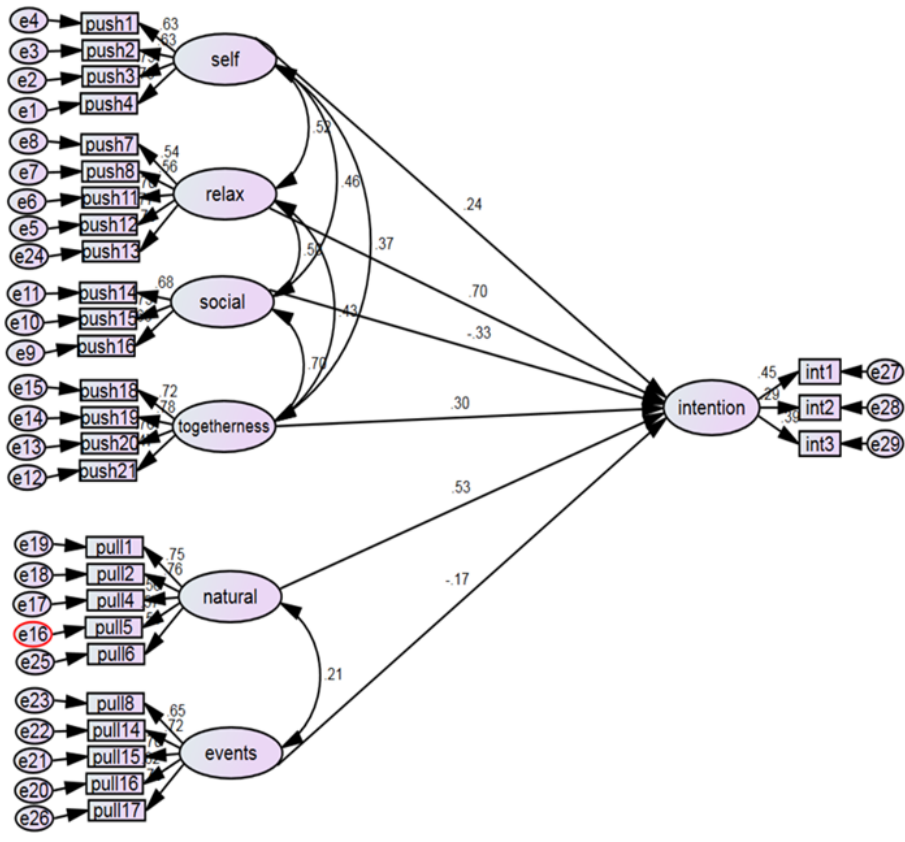

Source: Own research 


\section{JOURNAL OF TOURISM AND SERVICES}

Issue 22, volume 12, ISSN 1804-5650 (Online)

www.jots.cz

The objective to test the structural research model is to examine the causal relationship between domestic tourists' motivational factors, perceived benefits, perceived value, and behavioral intentions. The overall measurement summary is shown in Graph 5 and Table 5. The results show that the push motivational factors influence on perceived benefit $(\beta=.705, \mathrm{p}<.001),(\mathrm{H} 1)$; push motivational factors directly influence on revisit intention $(\beta=.202, \mathrm{p}<.001)$, (H5); perceived benefit influence on perceived value $(\beta=.632, p<.001),(H 3)$; and perceived value directly influence on revisit intention $(\beta=.657, p<.001)$, $(\mathrm{H} 4)$ were highly supported. The pull factors of travel motivation have a direct relationship $(\beta=-.130$, $\mathrm{p}<.001)$ with the behavioral intention, thus $\mathrm{H}_{6}$ was supported. On the contrary, the pull factors of travel motivations directly and positively influence on perceived benefit $(\beta=0.037, \mathrm{p}>.01) \mathrm{H}_{2}$ was rejected.

Table 5. The results of the direct relationships variable

\begin{tabular}{|c|l|c|c|c|c|c|}
\hline H & \multicolumn{1}{|c|}{ The path } & $\begin{array}{c}\text { Beta } \\
\text { estimate }\end{array}$ & S.E. & C.R. & P & Remark \\
\hline H1 & Per. benefit $\leftarrow$ Push M & 0.705 & 0.033 & 21.254 & .000 & Supported \\
\hline H4 & Behav.inten $\leftarrow$ Per.value & 0.657 & 0.037 & 17.726 & .000 & Supported \\
\hline H3 & Per.value $\leftarrow$ Per.benefit & 0.632 & 0.021 & 30.574 & .000 & Supported \\
\hline H5 & Behav.intent $\leftarrow$ PushM & 0.202 & 0.044 & 4.578 & .000 & Supported \\
\hline H6 & Behav.inten $\leftarrow$ PullM & -0.130 & 0.033 & -3.885 & .000 & Supported \\
\hline H2 & Per.benefit $\leftarrow$ PullM & 0.037 & 0.027 & 1.406 & .160 & Rejected \\
\hline Note: S.E; Standard Error. C.R; Critical Ratio. $* * * p<0.001, * * p<0.05, * p<0.1$. & \\
\hline
\end{tabular}

Source: Own research

\section{Graph 5. Research Model Output}

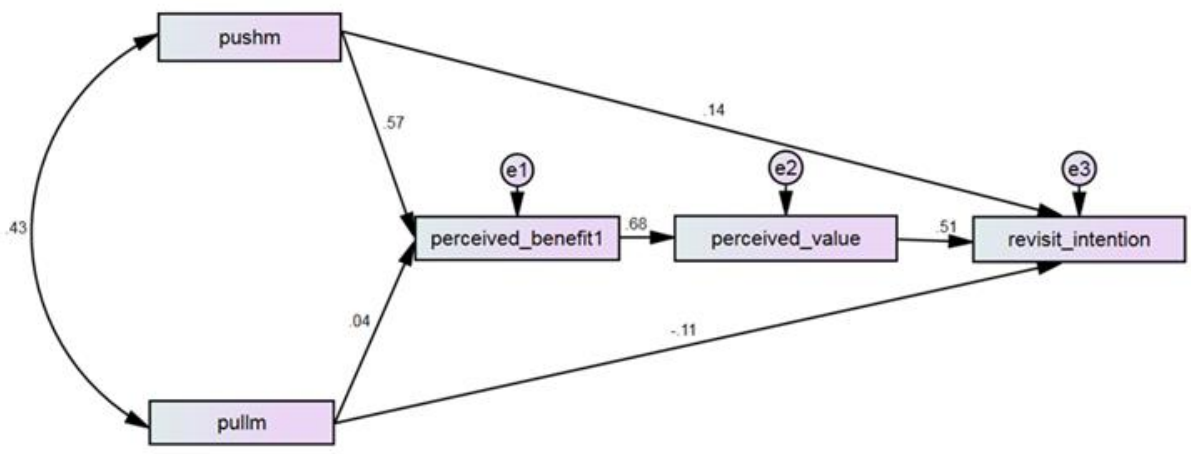

Source: Own research

\section{Discussion}

Domestic tourism is an essential tool to generate income and employment, achieve economic growth, enhance infrastructure, ease tourism seasonality, and regional development. Understanding of domestic tourists' behavior, travel motivations; and the relationship between perceived value and benefits are fundamental elements in achieving tourism development. Therefore, there are few academic studies 


\section{JOURNAL OF TOURISM AND SERVICES}

Issue 22, volume 12, ISSN 1804-5650 (Online)

www.jots.cz

that dedicated to investigate the relationship between domestic tourists' travel motivations, satisfaction, and behavioral intentions (Bayih \& Singh, 2020); direct effect of push and pull motives on domestic tourists' motivations (Baniya \& Paudel, 2016); identifications of domestic tourists' motivations in small islands (Canavan, 2016); and push and pull motivations of Indian domestic tourists to Kerala (Kanagaraj \& Bindu 2013). This empirical study attempts to understand domestic tourists' motivation, perceptions towards travel benefits and their behavioral intentions. Moreover, this study aims to contribute the theoretical and empirical evidence on causal relationships among push and pull motivations, perceived benefit, and perceived value and behavioral intentions in the case of Mongolian domestic tourists.

The findings identify relationships between 1) push and pull factors of travel motivations and perceived benefits; 2) perceived benefits and perceived value; 3) perceived value and behavioral intentions. The research aims to analyze whether domestic tourists in Mongolia expect perceived benefits from their travel that are affected by their push and pull factors of travel motivations or not. Thus, the research results indicated that both push and pull travel motivations directly and positively affect the perceived benefits of domestic tourists in Mongolia. The test result was statistically significant, therefore the research prediction of (H1) push motivation factors directly effect on behavioral intention was supported. However, pull travel factor of travel motivation directly and positively affecting perceived benefit (H2) was rejected ( $\beta=-037, \mathrm{p}>.01)$. The travel motivation (PUSH and PULL factors) results provide evidence that the relationship between push and pull travel motivations and behavioral intention was statistically supported. Furthermore, the relationship between perceived benefit, perceived value, and revisit intention was equally significant. However, there is no significant relationship between pull travel motivation on the perceived benefit of travel. The result shows that both PUSHM and PULLM have a positive relationship with behavioral intention and the relationship was significant $(p<0.05)$. All indicators show a good absolute model fit in one iteration (CMIN/DF; 5.907, RMSEA; 0.067; CFI; 0.839, TLI; 0.808, PNFI; 0.683). Moreover, the result identifies the important pull factors of travel motivations among Mongolian domestic tourists are: natural scenery, wide open space, sport and cultural activities, entertainment opportunities, sightseeing, and good natural atmosphere. However, 10 items from pull travel motivations (easy access to service and cultural factors) were excluded from the first order measurement due to the low relationship between variables. The path analysis coefficient and measurement model indicate only two pull factors of travel motivations; natural attractions, environment, and special events are important for Mongolian domestic tourists to decide where to travel within Mongolia. These results imply that 1) the important reason to travel in Mongolia for domestic tourists is spending a time with the family in nature than visiting cultural attractions, heritage or interested in local culture; 2$)$ the travel patterns of domestic tourists show that $(54.8 \%$ of respondents travelled with the family); they are less likely to travel by tour operators and prefer camping than staying in commercial tourist accommodations. This explains the low path coefficient of easy access to service. The research result further indicates that the push travel motivation significantly and positively relates to the revisit intention of tourist (CMIN/DF; 96.196; RMSEA; 0.296; PCLOSE; 0.000). TLI $(0.879<0.9)$ and CFI (0.909). The values were well above the threshold of 0.9 , which indicates a good incremental fit. This confirms the findings of a positive and direct relationship existing between travel motivations and tourists' revisit intention. The result clearly indicates that the most important push factors of travel motivation of domestic tourists in Mongolia are: excitement, self-exploratory (knowledge/education/new experience), relax and escapism, social achievement, and togetherness. Therefore, there is a relationship between push factors of travel motivation and revisit intention. Destination loyalty was assessed by the intention to repeat visitation to the destination, which include overall feelings about the visit, recommend destinations to others as a vacation place, and encourage friends and relatives to visit the destination. This is one of the important outcomes of the research; hence the ultimate goal of the destination marketers is to have a better understanding of the intrinsic and extrinsic motivations of tourists to travel to their destinations in order to satisfy them by providing highquality products and service. Furthermore, it leads more benefits to the destinations to increase repeat 


\section{JOURNAL OF TOURISM AND SERVICES}

Issue 22, volume 12, ISSN 1804-5650 (Online)

www.jots.cz

visitation of the tourists and recommendation of the destination to others. The research contributes to the body of knowledge by determining the push and pull motivational factors of domestic tourists, a stimulation of tourists to travel, and influence on the decision-making process for destination selection. The identification of the relationship between push and pull factors of travel motivations and behavioral intention is crucial for destination marketers, and tourism practitioners to understand domestic tourists' perceived benefits and perceived value from domestic travel in their own country.

Implication- The implication of this study relates to the identification of travel motivations for domestic tourists in Mongolia which is almost non-existent in tourism academic literature. As domestic tourism is becoming an important market segment for the tourism industry in Mongolia, this study is significant to policy makers and destination marketing organizations and domestic tourism suppliers. The results contribute to increasing the frequency of domestic travels, lengthening domestic tourists' stay, improving satisfaction, and increasing destination loyalty among domestic tourists in Mongolia. The research provides tourism stakeholders, service providers and tourism product developers important insights on the nature of the demands of domestic tourists and their visits to tourist destinations. The research concludes that natural environment, events, excitement, self-exploration, getting new knowledge and experience, relaxing and escapism, socializing, and togetherness are important factors for destination product development and marketing. Carefully researched efforts to design tourism products and services that correspond to the push and pull travel motivations of tourists are likely to lead to a positive perceived benefit and value of their travel; the latter to increase behavioral intentions and destination loyalty. The excitement, self-exploratory, new experience, and a sense of togetherness indicate that Mongolians are eager to learn new things and experiences while travelling in their own country with deliberate fun and enjoyment. The rural tourism products such as nomadic family stay could be developed in order to satisfy the needs of domestic tourists such as seeking new experience and self-exploration. Mura and Kljucnikov (2018) 's study reveal that rural tourism and agrotourism experience offer a holiday alternative for the people living in the busy lifestyle in urban area. Moreover, there is a need to carry out in-depth surveys that investigate the major reasons why Mongolians do not tend to use commercial tourism facilities and less interested in cultural aspects of pull travel motivations. Consequently, socio demographic characteristics of the study reveals that most domestic tourists were lower income earners and travelled with families. Therefore, there is need for developing children-friendly, family-oriented tourism service and activities offered by tourist destinations. In addition, destination management organizations, managers, and tourism product developers could improve access to tourists' attractions through provisions of reasonable product, service and appropriate marketing communication channels to meet the emerging demand of domestic tourism in Mongolia. Jupowicz-Ginalska and Patak (2018) emphasize the importance of marketing communication channels for the tourism sector since it is a way to build destinantion loyalty with customers. Overall, this study contributes to the literature on travel motivational studies in relation to domestic tourism in the context of a country in Asia. The in-depth examination of the intrinsic travel motivation is important for segmenting markets, designing marketing communication, and destination branding. It is considered that fundamental of marketing is to recognize the clearly defined motivations of client, which is a background for well-directed and focused marketing promotion. Therefore, the tourism practitioners in Mongolia could develop appropriate policy strategies and promotional programs based on the travel motivations of domestic tourists' market segments in order to satisfy their needs. Dann (1977) states that push and pull factors of travel motivations could further assist destination planners to increase and expand destinations' proposition by improving pull factors such as better prices, better service quality, and decent infrastructure. The push and pull travel motivational theory provides a stronger grip which factors are important to domestic tourists making destinations selection.

\section{Conclusion}




\section{JOURNAL OF TOURISM AND SERVICES}

Issue 22, volume 12, ISSN 1804-5650 (Online)

www.jots.cz

In conclusion, there are few academic studies dedicated to domestic tourists' travel motivations and the causal relationship between the aforementioned variables. Previous studies assessed (Huang \& Hsu, 2009; Lee \& Hsu, 2013) the push and pull factors of travel motivations relationship between destination loyalty and behavioral intentions (Khuong \& Ha, 2014). Tourism researchers (Balogu \& Uysal, 1996; Cha et al., 1995) researched human intrinsic desire (push factors) on travel needs and later more included extrinsic factors of travel (pull factor) motivations (Uysal \& Jurowski, 1994). The push travel motivations explain desire to travel to a certain destination and pull motivations explain the choice of destinations. Therefore, this study attempts to integrate both push and pull travel motivations as important elements and aims to analyze the significant relationship between perceived benefits, perceived values, and behavioral intentions. The output of research model supports direct effect of push and pull factors of travel motivations on perceived benefit, perceived value, and behavioral intentions. Finally, in regards to push and pull factors of travel motivations - perceived benefit - perceived value - behavioral intentions have sequential relationship, therefore a structured analysis of interrelationship among variables supported the proposed research model. The research findings indicate that it is essential to develop immediate domestic tourism policies and strategies in Mongolia. In order to have in-depth understanding of travel motivations of domestic tourists, future research is needed to improve the understanding of the significance of both push and pull factors on travel motivations, perceptions about the travel and behavioral intention. Additional attributes such as destination image, place attachment, satisfaction would be needed to investigate the relationship between push and pull travel motivations, perceived benefits and value, and behavioral intentions. Moreover, qualitative study on travel motivations of domestic tourists in Mongolia is highly recommended for further research.

\section{References}

1. Agrawal, S. (2017). Factors affecting tourist's satisfaction level at religious visit: a study of BrijKshetra. International Journal of Applied Research, 3(1), 848-852.

2. Amartuvshin, D. (2009). From community to holiday camps: the emergence of tourist economy in Mongolia", In Singh, S. (Ed), Domestic Tourism in Asia: Diversity and Divergence, Earthscan Dunsten House: London, 107-126. 9

3. Baloglu, S. \& Uysal, M. (1996). Market segments of push and pull motivations: a canonical correlation approach. International Journal of Contemporary Hospitality Management, 8(3), 16-30.

4. Baniya, R. \& Paudel, K. (2016). An analysis of push and pull travel motivations of domestic tourists in Nepal. Journal of Management and Development Studies, 27, 16-30

5. Bayih, B. E. \& Singh, A. (2020). Modeling domestic tourism: motivations, satisfaction and tourist behavioral intentions. Heliyon, 6(9), 1-17. https://doi.org/10.1016/j.heliyon.2020.e04839

6. Bigne, E., Sanchez, I. \& Sanchez-Garcia, J. (2001). Tourism image, evaluation variables and after purchase behaviour. Tourism Management,.22(6), 607-616.

7. Binder, J. (2004). The whole point of backpacking: anthropological perspectives on the characteristics of backpacking. In Richards, G., and Wilson, J. (Ed), The Global Nomad Backpacking Travel in Theory and Practice, Clevebon:Channel view publication, 99-108.

8. Bloom, J., Taris, T.W., Geurts, S. \& Sonnentag, S. (2010). Effects of vacation from work on health and well-being: lots of fun quickly gone. Work and Stress, 24(2), 196-216.

9. Bowen, D. \& Clark, J. (2009). Contemporary Tourist Behaviour - Yourself and Others as Tourists, CABI:London

10. Boydell, T. (1976). Experiental Learning, Direct Design:London

11. Brown, S. \& Lehto, X. (2005). Travelling with a purpose: understanding the motives and benefits of volunteer vacationers. Current Issues in Tourism, 8(6), 479-496.

12. Burton, S., Sheather, S. \& Roberts, J. (2003). The effect of actual and perceived performance on satisfaction and behavioural intentions. Journal of Service Research, 5(4), 292-302. 


\section{JOURNAL OF TOURISM AND SERVICES}

Issue 22, volume 12, ISSN 1804-5650 (Online)

www.jots.cz

13. Canavan, B. (2013). The extent and role of domestic tourism in a small island: the case of the Isle of Man. Journal of Travel Research, 52(3), 340-352. https:// doi:10.1177/0047287512467700

14. Cha, S., McCleary, K. W. \& Uysal, M. (1995). Travel motivations of Japanese overseas travellers: a factor-cluster segmentation approach. Journal of Travel Research, 34(1), 33-39.

15. Chen, C. C. \& Petrick, J. (2013). Health and wellness benefits of travel experiences: a literature review. Journal of Travel Research, 52(6), 709-719. https://doi:10.1177/0047287513496477

16. Chen, C. C. \& Petrick, J. (2014). The roles of perceived travel benefits, importance and constraints in predicting travel behavior. Journal of Travel Research, 55(4), 1-14. https://doi:10.1177/0047287514563986

17. Chen, C. F. \& Chen, F. S. (2010). Experience quality, perceived value, satisfaction, and behavior intentions for heritage tourists. Tourism Management, 31(1), 29-35.

18. Chen, C. F. \& Tsai, M. H. (2008). Perceived value, satisfaction, and loyalty of TV travel product shopping: involvement as a moderator.Tourism Management, 29(6), 1166-71.

19. Chi, X., Lee, S.K., Ahn, Y. J. \& Kiatkawsin, K. (2020). Tourist-Perceived Quality and Loyalty Intentions towards Rural Tourism in China. Sustainability. 12(9), 1-18. doi:10.3390/su12093614

20. China National Tourist Office in Singapore. (2021). Tourism Statistical Data. Viewed on 16 April, 2021. http://www.cnto.com.sg/

21. Cliff, N. (1987). Analyzing multivariate data. NewYork,NY: Harcourt Brace Jovanovich.

22. Correia, A., Kozak, M. \& Ferradeira, J. (2013). From tourist motivations to tourist satisfaction. International Journal of Culture, Tourism and Hospitality Research, 7(4), 411-424.

23. Dann, G. (1977). Anomie, ego-enhancement and tourism. Annals of Tourism Research, 4, 184-194.

24. Dolnicar, S., Coltman, T. \& Sharma, R. (2014). Do satisfied tourists really intend to come back? Three concerns with empirical studies linking satisfaction to behavioural intentions. Journal of Travel Research, 52, 152-178.

25. Frochot, I. \& Morrison, A. M. (2001). Benefit segmentation: a review of its applications to travel and tourism research. Journal of Travel and Tourism Marketing, 9(4), 21-45.

26. Gilbert, D. \& Terrata, M. (2001). An exploratory study of factors Japanese tourism demand for the UK. International Journal of Contemporary Hospitality Management, 13(2), 70-78.

27. Hair, J. F. J, Black, W. C., Babin, B. J. \& Anderson, R. E. (2010). Multivariate Data Analysis, Pearson Education: New Jersey

28. Hitka, M; Lorincova, S; Potkany, M; Balazova, Z; Caha, Z. (2021). Differentiated Approach to Employee Motivation in Terms of Finance. Journal of Business, Economics and Management, 22(1), 118-134. DOI: 10.3846/jbem.2020.13702

29. Hoelter, J. W. (1983). "The analysis of covariance structures: goodness-of-fit indices. Sociological Methods and Research, 11, 325-344.

30. Holbrook, M. B. (1999). Introduction to customer value. In Holbrook, M.B, (Ed), Consumer V alue: A Framework for Analysis and Research, Routledge:New York: Routledge, 1- 29.

31. Huang, S. \& Hsu, C.H. (2009). Effects of travel motivation, experience, perceived constraint, and attitudes on revisit intention. Journal of Travel Research, 48(1), 29-44.

32. Hwang, J., Asif, M. \& Lee, K. W. (2020). Relationships among Country Image, Tour Motivations, Tour Quality, Tour Satisfaction, and Attitudinal Loyalty: The Case of Chinese Travelers to Korea. Sustainability. 12(8), 1-19. doi:10.3390/su12083182

33. Iso-Ahola, S. E. (1982). Toward a social psychological theory of tourism motivation: a rejoinder. Annals of Tourism Research, 9(2), 256-262.

34. Jang, S. C. \& Cai, L. A. (2002). Travel motivations and destination choice: a study of British outbound market. Journal of Travel \& Tourism Marketing, 13(3), 111-113.

35. Jensen, J. M. (2011). The relationship between socio-demographic variables, travel motivations, and subsequent choice of vacation. International Conference on Economics, Business, and Management, IPEDR, Vol.22, Singapore 


\section{JOURNAL OF TOURISM AND SERVICES}

Issue 22, volume 12, ISSN 1804-5650 (Online)

www.jots.cz

36. Jupowicz-Ginalska, A. \& Patak, M. (2018). Management of travel and transport destinations' presentation in the travel specialized print media. International Journal of Entrepreneurial Knowledge, 6(2), 81-99.

37. Jurigova, Z. \& Lencsesva, Z. (2015). Monitoring system of sustainable development in cultural and mountain tourism destinations. Journal of Competitiveness, 7(1), 35-52

38. Kanagaraj, C. \& Bindu, T. (2013). An analysis of push and pull travel motivations of domestic tourists to Kerala. International Journal of Management and Business Studies, 3(2), 112-118.

39. Kassean, H. \& Gassita, R. (2013). Exploring tourists' push and pull motivations to visit Mauritius as holiday destination. Tourismos, 8(2), 39-56.

40. Katsikari, Ch., Hatzithomas, L., Fotiadis, T. \& Folinas, D. (2020). Push and Pull Travel Motivation: Segmentation of the Greek Market for Social Media. Sustainability. 12(11), 1-18. doi:10.3390/su12114770

41. Kenny, D. A., Kaniskan, B. \& McCoach, D. B. (2014). "The performance of RMSEA in Models with small degrees of freedom. Sociological Methodse Research, 44(3), 486-507. https://doi.org/10.1177\%2F0049124114543236

42. Keshavarzian, P. \& Wu, C. L. (2016). "A qualitative research on travellers' destination choice behaviour. International Journal of Tourism Research, 19, 546-556.

43. Khuong, M.N. \& Ha, H.T.T. (2014). The Influence of push and pull factors on the international leisure tourists' return intention to Ho Chi Minh City, Vietnam. International Journal of Trade, Economics and Finance, 5(6), 490-496. https://doi.org/10.7763/IJTEF.2014.V5.421

44. Kotler, P. T. \& Armstrong, G. (2017). Principles of Marketing, Pearson:London.

45. Kozak, M. (2002). Comparative analysis of tourist motivations by nationality and destinations. Tourism Management, 23(3), 221-232.

46. Kozicka K., Szopa R. (2016). Managing of tourist destinations offer based on the dynamics and forecast of tourist movement. Polish Journal of Management Studies, 114(2), 127-136. DOI:10.17512/pjms.2016.14.2.12

47. Kuo, Y. F. \& Feng, L. H. (2013). Relationships among community interaction characteristics, perceived benefits, community commitment, and oppositional brand loyalty in online brand communities. International Journal of Information Management, 33(6), 948-962. https://doi:10.1016/j.ijinformgt.2013.08.005

48. Kwenye, J. \& Freymund, W. A. (2016). Domestic tourists' loyalty to local natural tourist setting: examining from relational and transactional perspectives using a Zambian context. Tourism Management Perspectives, 20, 161-173. https://doi:10.1016/j.tmp.2016.08.006

49. Lee, C.K., Yoon, Y.S., \& Lee, S.K. (2007). Investigating the relationships among perceived value, satisfaction, and recommendations: the case of the Korean DMZ. Tourism Management, 28, 204 214.

50. Lee, D., O'Leary, J., Lee, S.H., \& Morrison, A. M. (2002). Comparison and contrast of push and pull motivational effects on trip behaviour: an application of multinomial logistic regression model. Tourism Analysis, 7(2), 84-104.

51. Lee, G. \& Lee, C. K. (2009). Cross-cultural comparison of the image of Guam perceived by Korean and Japanese leisure travellers: importance-performance analysis. Tourism Management, 30 , 922-931.

52. Lee, T.H. \& Hsu, F.Y. (2013). Examining how attending motivation and satisfaction affects the loyalty for attendees at aboriginal festivals. International Journal of Tourism Research, 15(1), 18-34.

53. Lin, P. J., Jones, E., \& Westwood, S. (2009). Perceived risk and risk relievers in online travel purchase intentions. Journal of Hospitality Marketing and Management, 18, 782-810.

54. Malhotra, N. (2007). Marketing research: An applied ori-entation. Upper Saddle River, NJ: Pearson Education

55. Mayo, E. J. \& Jarvis, L.P. (1981). The psychology of leisure travel, CBI Publishing Inc: Boston. 


\section{JOURNAL OF TOURISM AND SERVICES}

Issue 22, volume 12, ISSN 1804-5650 (Online)

www.jots.cz

56. Ministry of Environment and Tourism, MET n.d., Annual Report of the Ministry of Environment and Tourism, viewed on 12 May, 2020. https:/www.mne.mn/wp-content/uploads/2017/07/tailan.pdf.

57. Ministry of Tourism. (2019). India Tourism Statistics. Government of India, viewed on 16 April, 2021. https://tourism.gov.in/sites/default/files/2020 04/India\%20Tourism\%20Statistics\%202019.pdf

58. Morrison, A. M. (2013). Marketing and Managing Tourism Destinations. Oxon: Routledge

59. Muhammad, R., Ramli, N., Yusoff, N.M., \& Ismail, T.A.T. (2016). Are visitors satisfied and intend to revisit Rumah Terbuka Aidilfitri?: Malaysian community in Perak. Procedia -Social Behavioral Sciences, 222, 351-357. https://doi.org/10.1016/j.sbspro.2016.05.179

60. Mulaik, S., James, L. R., Alstine, J. V., Bennett, N., Lind. S. \& Stilwell, C. D. (1989). Evaluation of goodness-of fit for structural equation models. Psychological Bulletin, 105(3), 430-445.

61. Mura, L. \& Kljucnikov, A. (2018). Small business in rural tourism and agrotourism study from Slovakia, Economics and Sociology, 11(3), 286-300

62. Mussalam, G.O. \& Tajeddini, K. (2016). Tourism in Switzerland: How perceptions of place attributes for short and long holiday can influence destination choice. Journal of Hospitality and Tourism Management, 26,18-26.

63. Mutinda, R., and Mayaka, M. (2012), Application of destination choice model: factors influencing domestic tourists destination choice among residents of Nairobi, Kenya. Tourism Management, Vol.33, No 6, pp. 1593-1597.

64. Nambisan, S., \& Baron, R. A. (2009). Virtual customer environments: testing a model of voluntary participation in value co-creation activities. Journal of Product Innovation Management, 26(4), 388-406.

65. National Statistics Office of Mongolia, NSO n.d., Annual Tourism Statistical Data viewed on 12 May, 2020. https:/www.1212/Stat.aspx?LIST ID=976 L18\&type=tables

66. Niemczyk, A. \& Seweryn, R. (2014). Consumption of specific tourist products - the value of participation in mega-event and its in uence in shaping visitor loyalty to a destination. Journal of International Studies, 7(1), 109-121. DOI: 10.14254/2071-8330.2014/7-1/10

67. Oh, H. (1999). Service quality, customer satisfaction, and customer value: a holistic perspective. International Journal of Hospitality Management, 18(1), 67-82. https"//doi: 10.1016/S02784319(98)00047-4

68. Oppewal, H., Huybers, T. \& Crouch, G.I. (2015). Tourist destination and experience choice: a choice experimental analysis of decision sequence effect. Tourism Management, 48, 467-476.

69. Pallant, J. (2005). SPSS survival manual. Maidenhead, United Kingdom: Open University Press.

70. Pan, B. (2015). The power of search engine ranking for tourist destinations. Tourism Management, 47, 79-87. https://doi:10.1016/j.tourman.2014.08.015

71. Parasuraman, A., and Grewal, D. (2000). The impact of technology on the quality-value-loyalty chain: a research agenda. Journal of the Academy of Marketing Science, 28(1), 168-74.

72. Park, S.H., Lee, C.-K. \& Miller, J.C. (2015). A comparative study of the motivations, activities, overall satisfaction, and post-trip behaviors of international tourists in Macau: Mainland Chinese, Hong Kongese, Taiwanese, and Westerners. Asia Pacific Journal of Tourism Research, 20(10), 11741193. https://doi.org/10.1080/10941665.2014.965184

73. Pearce, P. L. (2005). Developing travel career approach to tourist motivations. Journal of Travel Research, 43(3), 227-237.

74. Pereira, V., Gupta, J. J. \& Hussain, S. (2019). Impact of travel motivation on tourist's attitude toward destination: Evidence of Mediating Effect of Destination Image. Journal of Hospitality \& Tourism Research. https://doi.org/10.1177/1096348019887528

75. Petrick, J. F. (2002). Development of a multi-dimensional scale for measuring the perceived value of a service. Journal of Leisure Research, 34(2), 119-134. 


\section{JOURNAL OF TOURISM AND SERVICES}

Issue 22, volume 12, ISSN 1804-5650 (Online)

www.jots.cz

76. Plangmarn, A., Mujtaba, B. G. \& Pirani, M. (2012). Cultural value and travel motivation of European tourists. Journal of Applied Business Research, 28(6), 1295-1304. https://doi.org/10.19030/jabr.v28i6.7344

77. Ryu, K., Han, H., \& Kim, T. H. (2008). The relationships among overall quick-casual restaurant image, perceived value, customer satisfaction, and behavioral intentions. International Journal of Hospitality Management, 27(3), 459-469. https://doi:10.1016/j.ijhm.2007.11.001

78. Sanchez, J., Callarisa, L., Rodriguez, R. M., \& Moliner, M. A. (2006). Perceived value of the purchase of a tourism product. Tourism Management, 27(3), 394-409. https://doi:10.1016/j.tourman.2004.11.007

79. Seyidov, J., \& Adomaitiene, R. (2016). Factors influencing local tourists' decision-making on choosing a destination: a case of Azerbaijan. Ekonomika, Vol. 95, No 3, pp. 112-127.

80. Shoemaker, S. \& Lewis, R. C. (1999). Customer loyalty: the future of hospitality marketing. International Journal of Hospitality Management, 18, 345-370.

81. Sirgy, M. J., Kruger, S., Lee. D.J., \& Yu, B.G. (2010). How does a travel trip affect tourists' life satisfaction. Journal of Travel Research, 50(3), 261-275. https://doi.org/10.1177/0047287510362784

82. Swarbrooke, J. \& Horner, S. (2005). Leisure Marketing: A Global Perspective. Oxford Burlington, MA by Elsevier Butterworth Heinemann

83. Tabachnick, B. G., \& Fidell, L. S. (2007). Using multivariate statistics. Upper Saddle River, NJ:Pearson.

84. Terblanche, N.S. \& Taljaard, A. (2018). The perceived value and perceived benefits experienced by customers using travel agents. South African Journal of Business Management 49(1), 1-13. a7. https://doi.org/10.4102/ sajbm.v49i1.7

85. Uysal, M. \& Hagan, L. A. (1993). Motivations of pleasure travel and tourism. in Khan, M., Olsen and T. Car. (Eds.), VNR's Encyclopedia of Hospitality and Tourism, 798-810. Van Nostrand Reinhold:New York

86. Uysal, M. \& Jurowski, C. (1994). Testing push and pull factors. Annals of Tourism Research, 21(4), 844-846.

87. Wang, Y. \& Fesenmaier, D. R. (2004). Modeling participation in an online travel community. Journal of Travel Research, 42(3), 261-270.

88. Wearing, S. \& Deane, B. (2003). Seeking self: Leisure and tourism on common ground. World Leisure, 45(1), 4-12.

89. Westman, M., Etzion, D. \& Gattenio, E. (2008). International business travels and the workfamily interface: a longitudinal study. Journal of Occupational and Organizational Psychology, 50(3), 261 275. https:// doi:10.1348/096317908x310265

90. Wong, B. K. M., Musa, G. \& Taha, A. Z. (2017). Malaysia my second home: the influence of push and pull motivations on satisfaction. Tourism Management, 61, 394-410.

91. World Bank Group. (2020). Covid 19 and Tourism in South East Asia-Opportunities for Sustainable Regional Tourism, Viewed $16 \quad 2021$. http://documents1.worldbank.org/curated/en/198651593536242978/pdf/COVID-19-andTourism-in-South-Asia-Opportunities-for-Sustainable-Regional-Outcomes.pdf

92. Yen, H. R., Hsu, S. H. Y., \& Huang, C. Y. (2011). Good soldiers on the web: understanding the drivers of participation in online communities of consumption. International Journal of Electronic Commerce, 15(4), 89-120.

93. Yoon, Y. \& Uysal, M. (2005). An examination of the effects of motivation and satisfaction on destination loyalty: a structural model. Tourism management, 26(1), 45-56. https://doi:10.1016/i.tourman.2003.03.016

94. Yu, L. \& Goulden, M. (2006). A comparative analysis of international tourists' satisfaction in Mongolia. Tourism Management, 27(6), 1331-1342. 


\title{
JOURNAL OF TOURISM AND SERVICES
}

Issue 22, volume 12, ISSN 1804-5650 (Online)

www.jots.cz

95. Závadský, J., Hitka, M., Potkány, M. Changes of employee motivation of Slovak enterprises due to global economic crisis. In E+M Ekonomie a management. 2015. 18 (1), pp 57-66. ISSN 1212 3609 DOI: $10.15240 /$ tul/001/2015-1-005

96. Zeithaml, A.V., Berry, L.L. \& Parasuraman, A.V. (1996). The behavioral consequences of service quality. Journal of Marketing, 60(2), 31-46. https://do:10.2307/1251929

\section{Brief description of Author/Authors:}

\author{
Oyunchimeg LUVSANDAVAAJAV* \\ ORCID ID: https://orcid.org/0000-0003-4306-5966 \\ Senior lecturer \\ National University of Mongolia, \\ Department of Geography \\ University street -1 P.O.BOX-46A/523, 14201 Ulaanbaatar, Mongolia \\ Contact phone number: (976)-99063594 \\ E-mail address: oyunchimeg_1@num.edu.mn
}

\section{PhD candidate*}

University of Pecs

Faculty of Business \& Economics

H-7622 Pécs, Vasvári Pál utca 4.

Tel: (36)702625190

Mrs. Oyunchimeg Luvsandavaajav currently holds the position as a senior lecturer of Tourism Studies at the Department of Geography, National University of Mongolia and PhD candidate at the University of Pecs, Hungary. She has gained her Masters of Tourism Management degree from Victoria University of Welling New Zealand. She has a wide range of research interests, including consumer behavior in tourism marketing, rural tourism, protected area tourism, community-based tourism, event tourism, responsible tourism, and sustainable tourism. Other active areas of research include sustainable development of rural communities, tourism geography and human geography, and geography of development studies in Inner Asia. She has worked on a diverse range of tourism projects, from contracted research with tourism industry stakeholders. Most recently, she has worked as a national expert at the ADB funded project focused on sustainable tourism development in the protected areas of Mongolia. She has published over 20 research papers in journals and presented at the international conference in China, Vietnam and Turkey. She has a wide range of professional experiences, including a vice director of the Juulchin World Tours Corporation in Mongolia. She received NZAid New Zealand Award for her master program and Stupendium Hungarcium Award for her PhD study in Hungary. She is trained in various tourism training programs at the Prince Songkla University in Thailand, MIB Trieste School of Management, Italy, James Cook University in Australia and Hong Kong Polytechnic University.

\section{Gantuya NARANTUYA, Ph.D,}

ORCID ID: https://orcid.org/0000-0002-1560-7388

\section{Senior lecturer}

National University of Mongolia

Department of Geography

University street-1 P.O.BOX-46A/523, 14201 Ulaanbaatar, Mongolia

Contact phone number: (976)-99036113

E-mail address:n.gantuya@num.edu.mn 


\section{JOURNAL OF TOURISM AND SERVICES}

Issue 22, volume 12, ISSN 1804-5650 (Online)

www.jots.cz

Dr. Gantuya Narantuya currently holds the position as a senior lecturer of Tourism Studies at the Department of Geography, National University of Mongolia. She has gained her $\mathrm{PhD}$ degree from Kumoh National Institute of Technology, South Korea and Masters of Tourism Management degree from National University of Mongolia. Dr. Gantuya's research interest focuses on tourism destination branding, place branding, regional tourism development, agro-tourism, as well as nature-based tourism and remote area tourism in Mongolia. Other active areas of research include marketing communication. She has published 12 research articles in international and national journals and presented 10 research papers in international conferences in Thailand, Vietnam China, Philippines and South Korea. Dr. Gantuya's research paper called "Antecedents of Travel Intentions to Mongolia" at the $3^{\text {rd }}$ International Conference on Digital Policy \& Management, 19-21 January, Ho Chi Minh, Vietnam won "Outstanding Paper Award". Besides her academic involvement, Dr. Gantuya has participated in various domestic and international projects on tourism development. Her recent projects are regional tourism development planning for Eastern Mongolia, and tourism labor market research in Mongolia. 